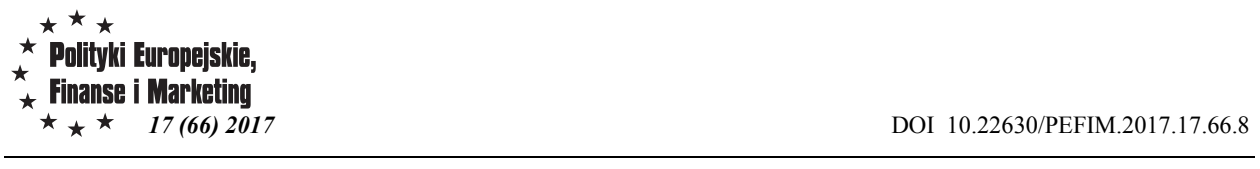

Adam Miara

Państwowa Wyższa Szkola Informatyki i Przedsiębiorczości w Lomży

\title{
Wpływ globalizacji na zarządzanie we współczesnym przedsiębiorstwie
}

\section{THE IMPACT OF GLOBALIZATION ON MANAGEMENT IN THE MODERN ENTERPRISE}

\begin{abstract}
Wieloaspektowość uwarunkowań funkcjonowania organizacji $w$ dobie globalizacji gospodarki światowej wymusza wybór i wdrażanie $w$ przedsiębiorstwach nowych metod zarzqdzania. W artykule podjęto próbę zaprezentowania skutków stosowania nowych, globalnych metod zarzadzania. Przedstawiono idee $i$ istote globalizacji $w$ odniesieniu do zarzadzania przedsiębiorstwem. Na podstawie przegladu literatury przedstawiono zalety oraz wady globalnych metod zarzadzania $w$ organizacjach.
\end{abstract}

Słowa kluczowe: zarządzanie, metody zarządzania, globalizacja

\section{Wstęp}

Od kilku dekad gospodarka światowa przechodzi diametralne zmiany związane z przyspieszeniem procesów globalizacji gospodarki światowej. Stało się to możliwe w warunkach względnej stabilizacji politycznej oraz szerokiego wykorzystania postępu technologicznej związanego z rewolucją informatyczną.

Nowe warunki powodują wzrost przepływu usług, towarów oraz kapitału, w tym inwestycji zagranicznych, technologii i informacji. Poszerza się również zasięg i zakres działania przedsiębiorstw, prowadząc do pogłębienia powiązań między krajami.

Globalizacja wymaga od przedsiębiorstw spełnienia oczekiwań klientów oraz osiaganie przewagi konkurencyjnej na coraz bardziej powiązanych rynkach. Osiaganie przewagi konkurencyjnej uzależnione jest od wprowadzania na rynek nowych produktów $i$ wdrażanie nowych technologii głównie $w$ małych $i$ średnich przedsiębiorstwach. Tylko sukces gwarantuje wysoką zyskowność. Wysokie zyski umożliwiają zebranie funduszy dla zapewnienia niezbędnego rozwoju, wykorzystując do tego celu inwestycje w nowoczesne technologie. Tylko takie przedsiębiorstwa mają dobrą reputacje wśród instytucji finansowych i bankowych, mogą liczyć na kredyty i uznanie wśród klientów.

Wielkie znaczenie dla rozwoju przedsiębiorstw i ich konkurencyjności na globalnym rynku ma wybór odpowiednich metod zarządzania. Zarządzania przedsiębiorstwem i związane $\mathrm{z}$ nim metody są niezaprzeczalnym elementem globalizacji współczesnego świata. Celem artykułu jest, próba określenia wpływu nowych metod zarządzania na współczesne polskie przedsiębiorstwo. 


\section{Pojęcie globalizacji i jej istota}

Globalizacja jest pojęciem, za pomocą którego próbowano opisać i wyjaśnić świat w ostatniej dekadzie XX wieku. Hasło to, choć powszechnie stosowane, jest niejednoznaczne i trudne do zdefiniowania. W bogatej literaturze przedmiotu można znaleźć wiele różnych definicji tego procesu. Brak jednoznacznego pojęcia wynika zapewne z wielowymiarowości i złożoności procesu globalizacji. Chodzi tu między innymi o wzrost skali, mobilności oraz integracji rynków finansowych, lub mówiąc inaczej o swobodne przemieszczanie się bilionów dolarów w poszukiwaniu zyskownych inwestycji. Jedna $\mathrm{z}$ najbardziej znanych definicji mówi, że globalizacja to rosnąca internacjonalizacja produkcji, dystrybucji i marketingu dóbr i usług. ${ }^{1}$ Według innej jest to intensyfikacja ekonomicznych politycznych i kulturowych stosunków przez granice. ${ }^{2}$ Według P. Bairoch i R. Kozul-Wright globalizacja to proces, w którym produkcja i struktury finansowe poszczególnych krajów stają się coraz bardziej powiązane poprzez zwiększającą się liczbę transakcji ponad granicami, prowadzonych do ukształtowania się nowego międzynarodowego podziału pracy, w którym tworzenie bogactwa na poziomie narodowym jest coraz bardziej uzależnione od podmiotów gospodarczych innych państw. Autorzy tej definicji uważają także, że globalizacja to ostatnie stadium integracji gospodarczej, w której tego typu uzależnienia osiaggają wymiar planetarny. ${ }^{3}$

Globalizacja jest wynikiem rozwoju sił wytwórczych oraz rewolucji technologicznej w szeroko pojętym komunikowaniu, zwłaszcza w gromadzeniu i przetwarzaniu danych. W praktyce globalizacja nie jest wyłącznie trendem w ekonomii, lecz oznacza wzrost różnego rodzaju połączeń we wszystkich dziedzinach życia społeczeństw (gospodarczym, kulturowym, technologicznym, politycznym i środowiskowym).

Analizując powyższe definicje można zauważyć, że w sposób niezwykle trafny akcentują one mnogość, rozległość, głębokość i wzajemność powiązań społeczeństw na etapie globalizacji. Definicja te - co jest bardzo istotne - zachowuje pełną użyteczność w odniesieniu do sfery ekonomicznej, w tym do procesów charakterystycznych dla gospodarki światowej ${ }^{4}$. Warto podkreślić, że w przedstawionej definicji stwierdza się istnienie pewnych cech procesu globalizacji, natomiast $\mathrm{W}$ niewielkim stopniu zaakcentowano jego dynamiczny charakter, który wynika z dwóch powodów ${ }^{5}$ :

- $\quad$ po pierwsze, należy modyfikować istniejące oraz tworzyć nowe powiązania i zależności w systemie światowym,

- po drugie, dokonujące się długofalowo zmiany w potencjale i układzie elementów światowego, systemu z upływem czasu implikują zmiany jego funkcjonowania. Zatem wewnętrzna dynamika procesu globalizacji może w istotny sposób kształtować jego ogólny przebieg, a w konsekwencji modyfikować strukturę oraz funkcjonowanie gospodarki światowej.

\footnotetext{
${ }^{1}$ R.G. Harris Globalization, Trade and Incom, „Candian Journal of Economics”, November 1993.

${ }^{2}$ P. Streeten, Globalization and Competitiveness, Implications for Development Thinking, Economic and Social Development into XXI Century, Washington D.C. 1997

${ }^{3}$ P. Bairoch, R. Kozul-Wright, Globalization Myths:Some Historical Reflections on Integration, Industralization and Growth in the World Economy, UNCTAD/OSG/ DP/113, March 1996

${ }^{4}$ A. Zorska, Ku globalizacji. Przemiany w korporacjach transnarodowych i w gospodarce światowej. Wyd.

Naukowe PWN, Warszawa 1998, s. 15.

${ }^{5}$ Tamże s 15.
} 
Globalizacja i związane $\mathrm{z}$ nią procesy zmieniają się bardzo dynamicznie, dlatego ich stopień i przebieg może się zmieniać w różnych dziedzinach. Może dotyczyć produkcji, przemysłu, technologii i wiedzy, rynków towarowych, jak i rynków usług, a także wzorców konsumpcji i kultury masowej.

\section{Globalizacja a zarządzanie}

Metody zarządzania stosowane w przedsiębiorstwie w dużej mierze zależą od zmiany zachodzących w gospodarce światowej. Do tych zmian, które określane są często mianem światowych trendów rozwoju, należą w ostatnich latach przede wszystkim ${ }^{6}$ :

- globalizacja gospodarki światowej i związany z nią wzrost liczby powiązań gospodarczych między poszczególnymi krajami, przedsiębiorstwami;

- ograniczenie niezależności gospodarczej państw będące efektem spadku znaczenia wpływu granic na działalność handlową, a co za tym idzie - swoboda przepływu kapitału, techniki, dóbr, ludzi, usług, informacji, a w efekcie również idei, poglądów, koncepcji intelektualnych i stylów zarządzania;

- aktywizacja i dążenie do internacjonalizacji działania małych i średnich przedsiębiorstw poprzez wykorzystanie innowacyjności, operatywności i dużej zdolności adaptacyjnej do zmieniających się warunków działania;

- $\quad$ powstanie jednolitego rynku, na którym przestaną istnieć bariery i ukształtują się nowe relacje gospodarcze, nastąpi wzrost konkurencji międzynarodowej, czynnikiem warunkującym zmiany w sytuacji rynkowej będą nowe technologie przyspieszające tempo innowacji oraz proces ich weryfikacji na rynku, spadnie rola ceny, a wzrośnie znaczenie totalnej jakości i agresywnego marketingu;

- zmiana stylów życia, będąca konsekwencją starzenia się społeczeństw, zmiany systemów wartości, gustów i upodobań oraz rosnącej roli zdrowego środowiska w podnoszeniu jakości życia;

- $\quad$ konieczność upodmiotowienia pracowników poprzez stwarzanie im możliwości rozwoju zawodowego, partycypacji $\mathrm{w}$ korzyściach związanych $\mathrm{z}$ rozwojem przedsiębiorstwa poprzez podnoszenie wagi ich pracy oraz poprawę warunków pracy;

- rosnąca liczba możliwych alternatyw wyboru zawodu oraz miejsca pracy, wzrost oczekiwań i aspiracji tzw. ludzi nowych wartości jako lepiej wykształconych i oczekujących szybszych karier zawodowych;

- wydłużanie horyzontu czasowego niezbędnego w procesie podejmowania decyzji gospodarczych

- $\quad$ oraz wzrost czynnika czasu w walce konkurencyjnej i zaspokajaniu potrzeb rynku;

- głęboki i nieodwracalny w skutkach kryzys hierarchicznych struktur zarządzania, szybka decentralizacja organizacji i hierarchii, powstawanie sieci przetwarzania informacji, a także zasadnicze zmiany w strukturze zarządzania;

- pełniejsza transformacja gospodarki industrialnej w gospodarkę informacyjną, szeroki przepływ informacji, ułatwiający nawiązywanie stosunków handlowoprodukcyjnych, tworzenie wspólnych przedsiębiorstw, zdobywanie nowych

${ }^{6}$ J. Penc, Strategie zarządzania. Agencja Wydawnicza PLACET, Warszawa 2002, s. 59. 
segmentów rynku, tworzenie nowych sieci sprzedaży i produkowanie wyrobów dostosowanych do potrzeb lokalnych rynków zagranicznych niezależnie od ich położenia geograficznego.

Wskazane przemiany zachodzące w gospodarce światowej w dużej mierze mają wpływ na kształtowanie się nowoczesnych metod zarządzania, które muszą umożliwić reagowanie na zmiany. Jest to podyktowane przede wszystkim koniecznością zapewnienia przewagi konkurencyjnej, satysfakcji odbiorców oraz osiagnnięcia innych celów wynikających z przedmiotu działalności przedsiębiorstwa ${ }^{7}$.

W swojej książce „Zarządzanie w XXI wieku” Drucker podkreśla, że efektywne zarządzanie przedsiębiorstwem XXI wieku opiera się na nowych paradygmatach oraz racjonalnych instrumentach zarządzania, których istotą jest odejście od schematyzmu, uznanie gwałtownej dynamiki zmian otoczenia przedsiębiorstwa oraz różnorodności warunków funkcjonowania przedsiębiorstw. ${ }^{8}$ Wszystko to powoduje u przedsiębiorców konieczność wykazywania większej otwartości na innowacje, w tym innowacje w zarządzaniu na które polskie przedsiębiorstwa są otwarte.

Wykres 1. Metody zarządzania wykorzystywane przez polskie przedsiębiorstwa.

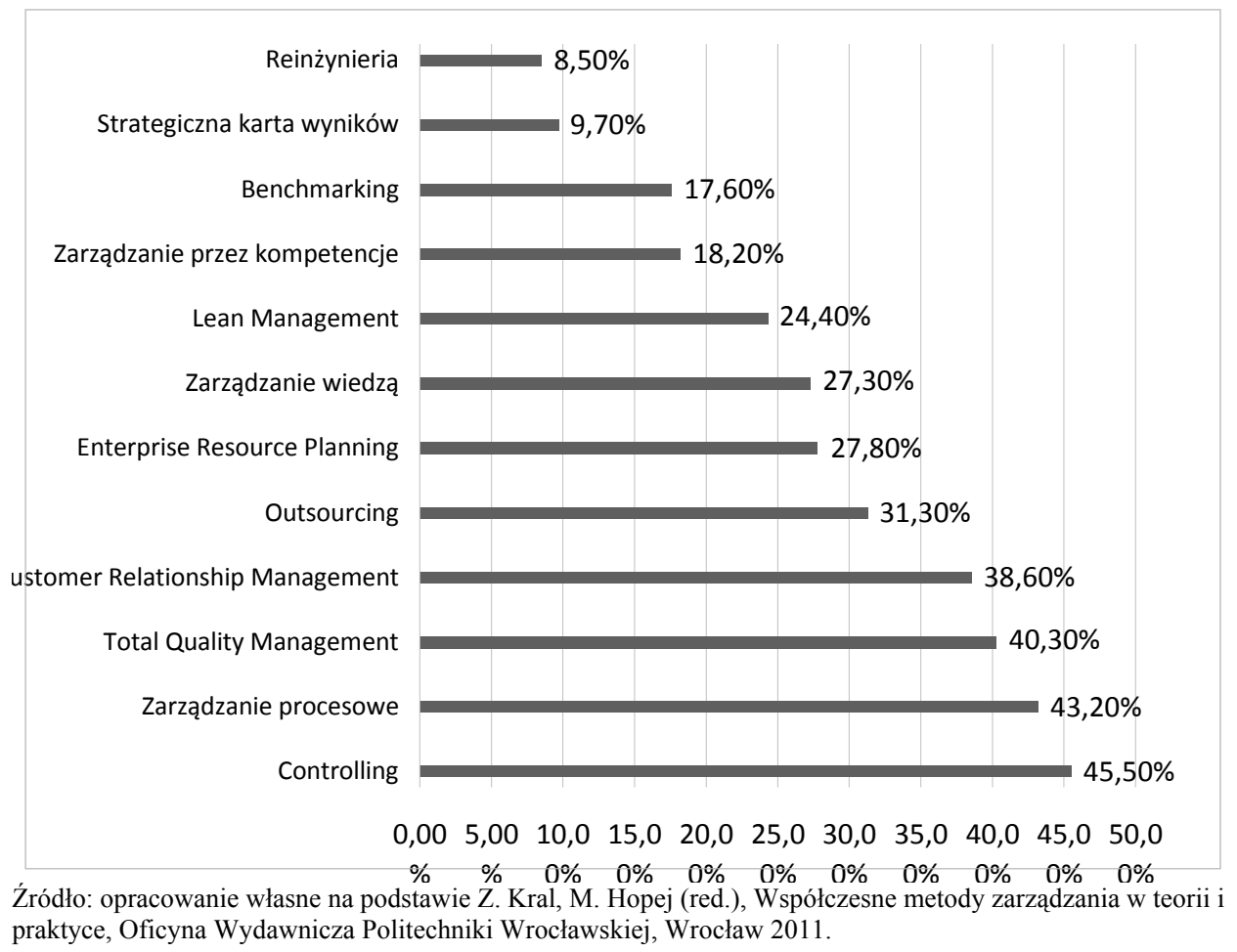

${ }^{7}$ A. I Szymańska, Globalizacja a nowe koncepcje zarządzania przedsiębiorstwem, Przedsiębiorczość Edukacja, $2012 \mid 8$ Rola przedsiębiorczości w edukacji. s. 365.

${ }^{8}$ P.F Drucker, Zarządzanie w XXI wieku. Muza, Warszawa 2000, s. 41. 
W świetle danych zaprezentowanych na powyższym rysunku okazuje się, że zdecydowanie najczęściej wdrażaną współczesną metodą zarządzania w przedsiębiorstwach jest zarządzanie procesowe, których podstawą są pierwsze trzy metody, które uzyskały największą liczbę wskazań przez przedsiębiorstwa (controlling $45,5 \%$, zarządzanie procesowe $43,20 \%$, TQM 40,30\%). Na drugim biegunie mamy metody, które oparte są o analizę statystyczną (reiżynieria 8,5\%, strategiczna karta wyników 9,7\%). Pozostałe metody oparte są w dużej mierze na pozyskiwaniu wiedzy i zarządzania nią (np. benchmarking 17,6\%, zarządzanie przez kompetencje 18,2 \%, zarządzanie wiedzą 27,3\%).

Zaprezentowane wyniki wskazują na hierarchie ważności metod zarządzania. $\mathrm{Na}$ pierwszym miejscu są metody oparte na zarządzaniu procesowym, na drugim metody oparte na zarządzaniu wiedzą. Na końcu natomiast są te metody, których podstawą jest analiza statystyczna.

\section{Zalety i wady stosowania globalnych metod zarządzania}

Wykorzystywane przez polskie przedsiębiorstwa koncepcje zarządzania wywodzą się z Japonii i Stanów Zjednoczonych. Ich wdrożenie wpływa na wiele aspektów działalności przedsiębiorstw.

Wykres 2. Wpływ metod zarządzania na wybrane aspekty zarządzania przedsiębiorstwem.

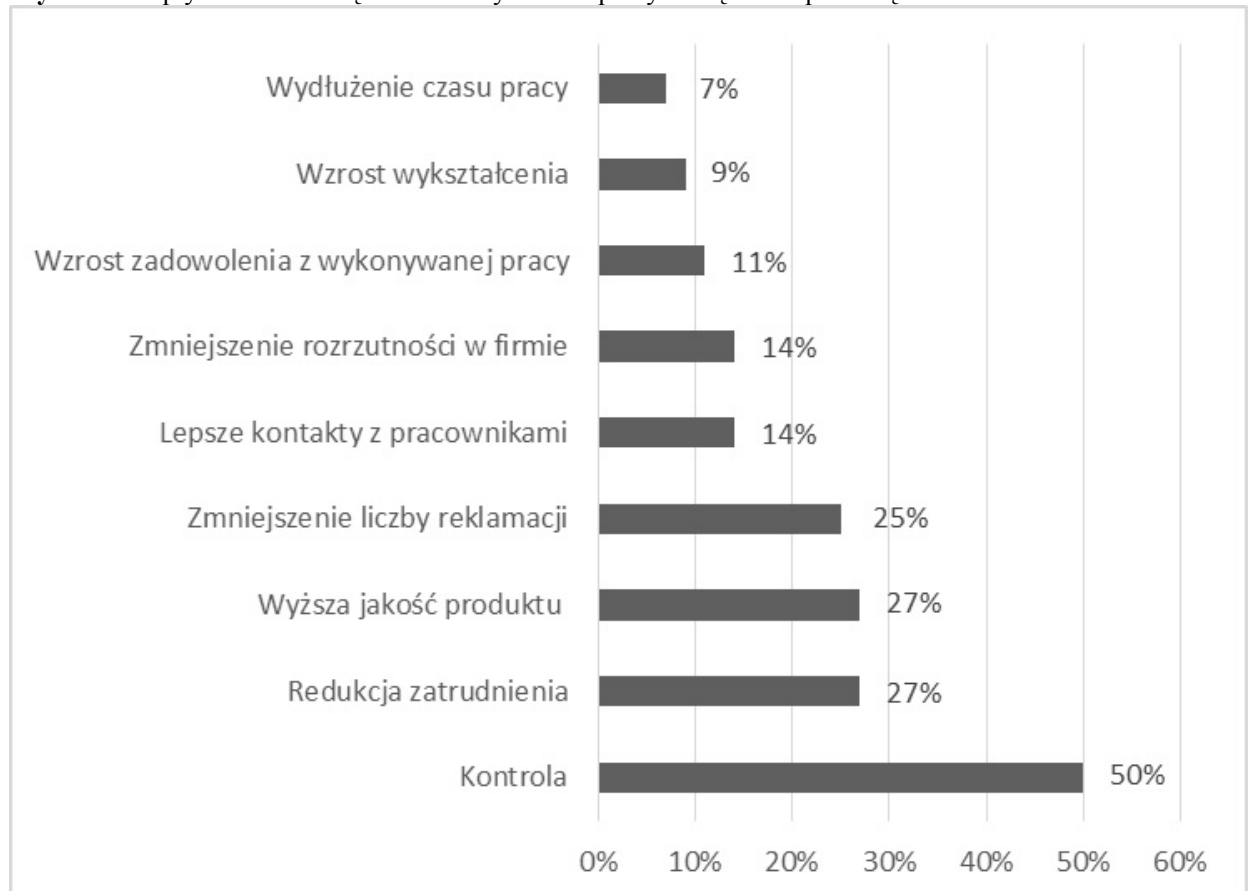

Źródło: opracowanie własne na podstawie: M. Podobiński, Skutki stosowania japońskich koncepcji i metod zarządzania w polskim, Nauki o Zarządzaniu, nr 1 (18)2014 
Wyniki badań zaprezentowane w tabeli powyżej pozwalają stwierdzić że wskazane aspekty mają $\mathrm{w}$ zdecydowanej większości pozytywny wpływ na przedsiębiorstwo. Są również takie, których wpływ może być negatywny lub pozytywny, co zależy od strony która to ocenia (pracodawca czy pracownik). W przypadku jednego czynnika (wydłużenie czasu pracy) wpływ ten należy określić jako zdecydowanie negatywny. Wynika to $z$ faktu, iż nowe metody zarządzania wymagają opracowania określonych procedur i przeprowadzania kontroli, co w początkowej fazie wdrażania koncepcji, może rzeczywiście wydłużać czas niezbędny do realizacji poszczególnych procesów.

Zdaniem badanych przedsiębiorstw wdrożenie nowych koncepcji zarządzania pozytywnie na wpływa na produkt. Wyższa jakość wyrobów (najczęściej zaznaczona odpowiedź przez respondentów - 27\%), która wynika ze zmniejszenia liczby reklamacji (drugi wynik - 25\%) spowodowana jest stosowaniem metod i narzędzi doskonalenia procesów, kontroli oraz kompleksowego zarządzania jakością. Wyższa jakość produktu to również zasługa kapitału ludzkiego. Wzrostu wykształcenia pracowników (większa wiedza specjalistyczna oraz większa wiedza na temat procesów realizowanych w firmie) wpływa na ich świadomość oraz umiejętność rozwiązywania problemów, które niewątpliwie decydują o prawidłowej realizacji procesów $\mathrm{w}$ przedsiębiorstwie. Na jakość produkcji wpływ ma również lepszy kontakt z pracownikami (14\%), który wpływa na zmniejszenie barier komunikacyjnych, prze co są on zrozumiałe i jednoznaczne. Poprawiła się również komunikacja, a to skutkuje lepszą atmosferą w pracy, przez co pracownicy są bardziej zmotywowani do wykonywania powierzonych im zadań.

Do zalet można również zaliczyć zmniejszenie rozrzutności (14\%), które wpływa na lepsze wykorzystanie posiadanych zasobów niezbędnych do realizacji procesów. Wpływa to obniżenie kosztów, co przekłada się na wzrost zysków, które mogą być dalej inwestowane, co w konsekwencji przełoży się ponownie na wzrost przychodów i zysków. Dzięki temu przedsiębiorstwo lepiej wykorzystuje zasoby, obniżając przy tym koszty.

Oprócz niezaprzeczalnych korzyści wynikających z wprowadzania nowych metod zarządzania są też aspekty, których jednoznaczna ocena jest bardzo trudna i zależy od oceniającego. Do pierwszych z nich należy kontrola. Aż połowa badanych wskazała, że nowe metody zarządzania wprowadzają zwiększoną kontrolę. Z jednej strony wzrost kontroli procesów powoduje mniejsze koszty wynikające np. z błędów i pomyłek (spojrzenie pracodawcy), z drugiej strony ma ona charakter negatywny i źle się kojarzy pracownikom. Należy jednak zwrócić uwagę, że kontrola jest jedną z czterech funkcji zarządzania i pełni bardzo ważną rolę. Ma za zadanie porównanie planu z jego realizacją oraz usprawnić proces. Jeżeli występują różnice, to trzeba je zidentyfikować, znaleźć ich przyczynę i wyeliminować. Ciągłe kontrolowanie nie ma wprowadzić złej atmosfery w pracy, braku zaufania, jej celem jest ciagłe usprawnienie

Kolejnym niejednoznacznym aspektem w ocenie respondentów jest redukcja załogi, którą wskazało 27\%. Również badania opublikowane w niemieckim „Management Zeitscrift” wskazują redukcję załogi (54\%) jako bardzo ważny czynnik 
wdrażanie nowoczesnych metod zarządzania ${ }^{9}$. Zwolnienie pracownika jest zawsze trudną decyzją, tym bardziej że wiąże się to ze stratą wykwalifikowanego personelu, który zna organizację. Jednak nowe globalne metody zarządzania powodują znaczne usprawnienie organizacji, co w dużym stopniu przekłada się na wydajność, a to z kolei powoduje często konieczność redukcji personelu. Zaoszczędzone środki finansowe wpływają na dalszy dynamiczny rozwój organizacji, co w dobie globalizacji gospodarki światowej jest nieodzownym elementem wzrostu konkurencyjności.

\section{Podsumowanie}

Globalizacja gospodarki, niewątpliwie spowodowała konieczność zastąpienia stosowanych wcześniej koncepcji zarządzania, nowymi bardziej efektywnymi sprawdzającymi się w nowych warunkach gospodarczych. Z przeprowadzonych badań wynika, że najbardziej popularne oparte są o zarządzanie procesowe, uwzględniające interesy wszystkich zainteresowanych stron. Należy jednak pamiętać, że wdrożenie nowych metod zarządzania jest procesem długotrwałym. Dopiero po upływie kilku lub kilkunastu lat można spodziewać się trwałych pozytywnych wyników. Dlatego tak istotne jest wsparcie najwyższej kadry kierowniczej, poprzez szkolenia, wyjazdy studyjne czy staże w zagranicznych firmach. Zdobycie wiedzy i doświadczenia wpłynie na postrzeganie przedsiębiorstwa, nie przez pryzmat wyników kwartalnych, lecz prze pryzmat przynajmniej jednego roku. $\mathrm{W}$ długim nowe metody zarządzania powodują poprawę wyników produkcji, zwiększenie jakości, zmniejszają liczbę reklamacji, a to doprowadza do rozwoju organizacji, poprawy wizerunku, zwiększenia liczby zamówień. To „wymusza” na firmach budowanie nowych inwestycji powodujących wzrost zatrudnienia.

\section{Bibliografia}

Bairoch P., Kozul-Wright R.: Globalization Myths:Some Historical Reflections on Integration, Industralization and Growth in the World Economy, UNCTAD/OSG/DP/113, March 1996.

Drucker P.F.: Zarządzanie w XXI wieku, Muza, Warszawa 2000.

Harris Globalization R.G.: Trade and Incom, „Candian Journal of Economics”, November 1993.

Kral Z., Hopej M.: (red.), Współczesne metody zarządzania w teorii i praktyce, Oficyna Wydawnicza Politechniki Wrocławskiej, Wrocław 2011.

Penc J.: Strategie zarządzania, Agencja Wydawnicza PLACET, Warszawa 2002.

Podobiński M.: Skutki stosowania japońskich koncepcji i metod zarządzania w polskim, Nauki o Zarządzaniu, nr 1 (18)2014.

Streeten P.: Globalization and Competitiveness, Implications for Development Thinking, Economic and Social Development into XXI Century, Washington D.C. 1997

Szymańska A.I.: Globalizacja a nowe koncepcje zarządzania przedsiębiorstwem, Przedsiębiorczość - Edukacja, 2012 | 8 Rola przedsiębiorczości w edukacji.

Zorska A.: Ku globalizacji. Przemiany $\mathrm{w}$ korporacjach transnarodowych i $\mathrm{w}$ gospodarce światowej., Wyd. Naukowe PWN, Warszawa 1998.

\footnotetext{
${ }^{9}$ M. Podobiński, Skutki stosowania japońskich koncepcji i metod zarządzania w polskim. Nauki o Zarządzaniu, nr 1 (18)2014, s. 83
} 


\section{Summary}

Many aspects functioning of an organization of conditions in a globalizing world economy forces the selection and implementation of enterprise new management methods. This article attempts to present the effects new global of management methods. Presents the idea and essence of globalization in relation to business management. Based on the review of the literature shows the advantages and disadvantages of global management methods in organizations.

Key words: management, management methods, globalization

\section{Informacja o autorze}

dr Adam Miara

Państwowa Wyższa Szkoła Informatyki i Przedsiębiorczości w Łomży

Tel.667002383,email amiara@pwsip.edu.pl 